\title{
Shear stress in subducting continental margin from high-pressure, moderate-temperature metamorphism in the Ordenes Complex, Galicia, NW Spain
}

\author{
J. Alcock ${ }^{\mathrm{a}, *}$, Ricardo Arenas ${ }^{\mathrm{b}}$, José R. Martínez Catalán ${ }^{\mathrm{c}}$ \\ a Department of Environmental Sciences, Abington College, Penn State University, Abington, PA 19001, USA \\ ${ }^{\mathrm{b}}$ Departamento de Petrología y Geoquímica, Universidad Complutense, 28040 Madrid, Spain \\ ${ }^{\mathrm{c}}$ Departamento de Geologia, Universidad de Salamanca, 37008 Salamanca, Spain
}

\begin{abstract}
The Ordenes Complex, Galicia, NW Spain, preserves high-pressure, moderate-temperature metamorphism in continental margin rocks subducted during closure of the Rheic Ocean in the Variscan orogeny. The exposures extend across $\approx 90 \mathrm{~km}$ perpendicular to strike and include rocks that reached depths of 30 to $60 \mathrm{~km}$. Estimates of $P-T$ conditions of rocks found near the boundary between overriding and subducting plates range from $430{ }^{\circ} \mathrm{C}$ at $1.0 \mathrm{GPa}$ to $520{ }^{\circ} \mathrm{C}$ at $1.65 \mathrm{GPa}$. Structural reconstructions including these data indicate an angle of subduction between 15 and $30^{\circ}$.

A mathematical solution and numerical models have been used to estimate shear heating experienced by this well-exposed paleo-subduction zone. Best fit of model to thermobarometric results occurs if shear stress in the upper reaches of the fault separating subducting and overriding slabs was $\approx 100 \mathrm{MPa}$ (constant shear) or $\approx 10.0 \%$ of pressure (constant coefficient of friction) assuming a convergence rate of $6 \mathrm{~cm}$ year ${ }^{-1}$. At greater depths negative feedback between temperature and shear stress caused the system to approach steady state with decreasing shear stress and with little increase in temperature. The decrease in shear stress at temperatures above $400{ }^{\circ} \mathrm{C}$ occurs as the rheological properties of the rock at higher temperature and (or) pressure allow more plastic behavior. This suggests that high-temperature metamorphism is unlikely to occur in subducting crust without special circumstances. A comparison of these results with estimates of shear stress inferred from seismicity and heat flow at active convergent boundaries in the Pacific indicates that shear stress is best described as a pressure-dependent variable not as a constant shear stress.
\end{abstract}

Keywords: Shear stress; Subduction; High-pressure metamorphism; Mathematical and numerical models; Variscan orogeny; Northwest Spain

\footnotetext{
* Corresponding author. Tel.: +1 215881 7356; fax: +1 2158817623.
}

E-mail address: jea4@psu.edu (J. Alcock). 


\section{Introduction}

Understanding processes that lead to high-pressure, low to moderate-temperature regional metamorphism is a goal of gelogic research in areas affected by past and present plate convergence. The effects of underthrusting on the formation of blueschist and eclogite facies assemblages remains an important theme of this work, especially the efforts to better understand the nature of shear forces along the main underthrust and their impact on the thermal regime of the subducting crust (Graham and England, 1976; van der Beukel and Wortel, 1987; Mølnar and England, 1990; Peacock, 1992, 1996). This problem has been appreached in a variety of ways including measurement of heat flow to the surface above subducting crust (e.g. Tichelaar and Ruff, 1993; Springer, 1999; Von Herzen et al., 2001), using the depth of seismically active crust to estimate temperature gradients along the thrust (Tichelaar and Ruff, 1993; Peacock and Wang, 1999), and pressure-temperatures conditions inferred frøm blueschist and eclogitic rocks (Peacøck, 1990, 1992, 1996). Each method relies on thermal models to estimate the contributions of various heat sources within the subduction zone. Typically heat that carmot be explained as derived from normal mantle flux or radiogenic sources is interpreted to result from shear heating (England and Richardson, 1977; England and Thompson, 1984; Peacock, 1990; Tichelaar and Ruff, 1993; Emst and Peacock, 1996; Springer, 1999; Von Herzen et al., 2001).

The Basal Units of the Ordenes Complex, Galicia, NW Spain, are comprised of subducted continental margin røcks. This pale-convergent margin is currently exposed across $\approx \mathbf{9 0} \mathrm{km}$ perpendicular to the strike of the orogen. Relict mineral assemblages in porphyr blasts have been used to determine pressure-temperature conditions during subduction. Estimates consistently increase frøm east to west, current cœordinates, frøm $430^{\circ} \mathrm{C}$ at $1.0 \mathrm{GPa}$ to $520^{\circ} \mathrm{C}$ at $1.65 \mathrm{GPa}$. In this paper we report results of models using the constraints provided by these data to better understand how shear stress impacted metamorphism of the Basal Unit during subduction.

\section{Geologic setting}

The Iberian Massif of northwest Spain is characterized by three allochthonous complexes thrust ont Upper Proterøic and Paleøic sequences and intruded by syn- to postkinematic Variscan granit॰ids (Fig. 1). The complexes consist of three grøups of units, Upper, Ophiolitic and Basal, that were stacked during the closure of the Rheic Ocean at the beginning -f the Variscan orogeny. The Upper Units represent pieces of a suspect terrane, probably an island arc (Andonaegui et al., 2002), and the Ophiølitic Units, below, are fragments of $\bullet$ ceanic lith $\bullet$ sphere of the Rheic Ocean or of basins marginal to it. The Basal Units represent the outermost edge of the northern passive margin of Gendwana, and underwent subduction below the accretionary prism formed previ-usly by the stacking of Upper and Ophiølitic Units (Martínez Catalán et al., 1996, 1997, 2002). Their subduction marked the transition from $\bullet$ ceanic closure to Variscan collision, and was followed by their exhumation along large thrusts, helped by the thinning -f the overlying orøgenic wedge by extensional detachments.

Ordenes is the largest of the alløchthønous complexes in NW Spain and is exposed as a klippe, preserved in a late-Variscan synform. The four Basal Units ๑utcrop along its søuthern and western margins (Figs. 1 and 2A). These Units consist of metasediments (schists and paragneisses), amphibelites and orthøgneisses. The latter are extremely flattened metagranites of Ordovician age, and constitute, together with the amphibølites, excellent markers to identify large structures. From them it can be established that the Santiage, Lalín, and Forcarei Units were initially continuous (and remain nearly s•) and became folded in a recumbent antiform, carried to the east by the Lalín-Forcarei thrust and cut by the late Pic• Sacr extensiønal detachment (Fig. 2A).

High-pressure metamorphism has been identified in the Basal Units. Pressure-temperature $(P-T)$ conditions were established using micrøinclusions of the oldest-fine-grained foliation preserved in albite porphyroblasts (Arenas et al., 1995) in schists and in relict ecløgite bøudins (Arenas et al., 1997; Rubi॰ Pascual et al., 2002). The metamorphic conditions reached during the high-pressure metamorphism in the Santiage Unit (location C) were $650 \mathrm{MPa}$ and 90 

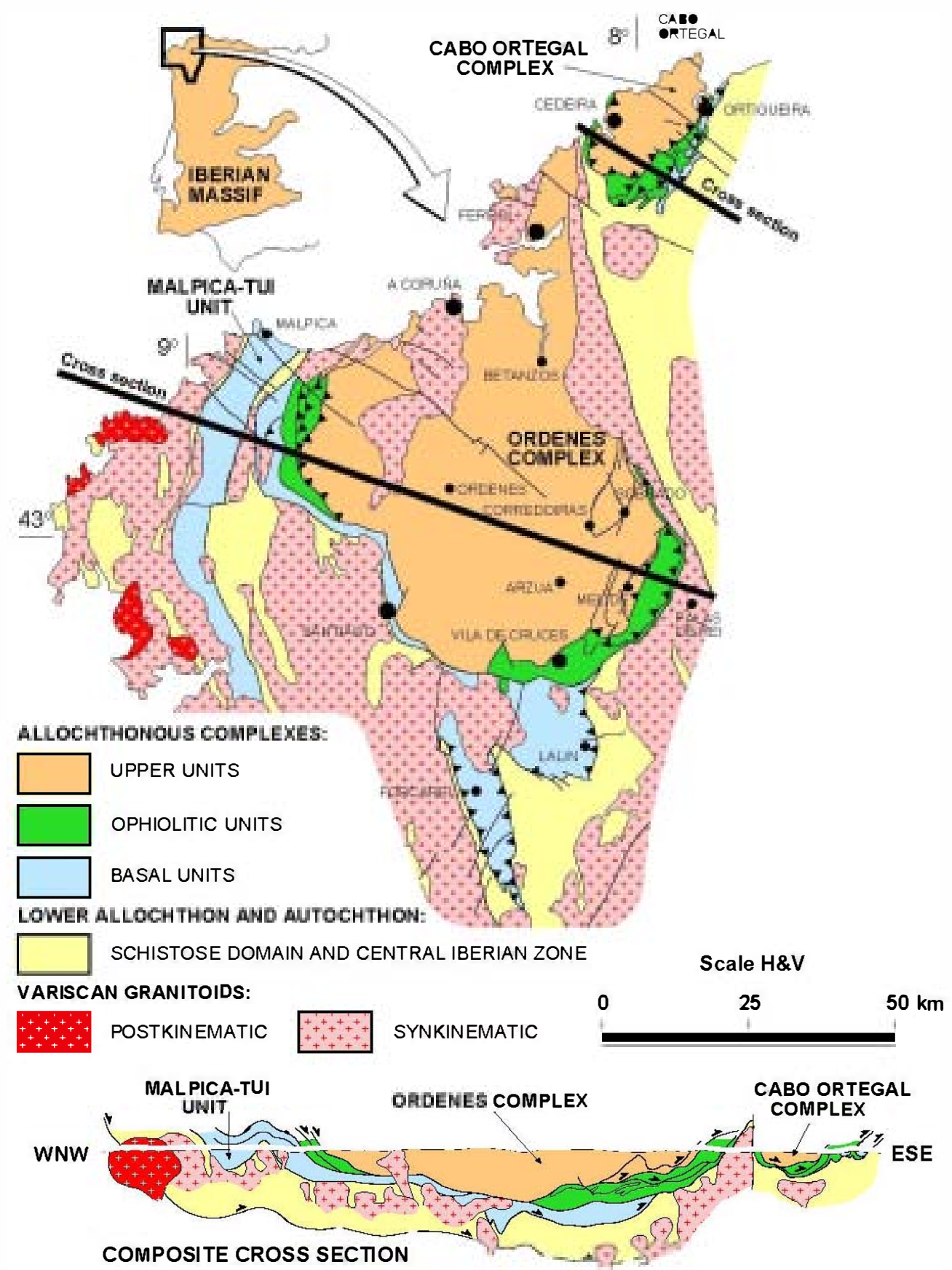

Fig. 1. Geological sketch-map and cross-section of NW Spain showing the three allochthonous complexes of Cabo -rtegal, Ordenes and Malpica-Tui.

- $\mathrm{C}$ higher than in the Forcarei Unit (location A), implying a sense of subduction toward the west (in present coordinates; see Fig. 2 and Table 1). More- -ver, evidence of heat advection transferred from above in the upper part of the Santiage and Lalín Units (Martínez Catalán et al., 1996, 2002) and the 


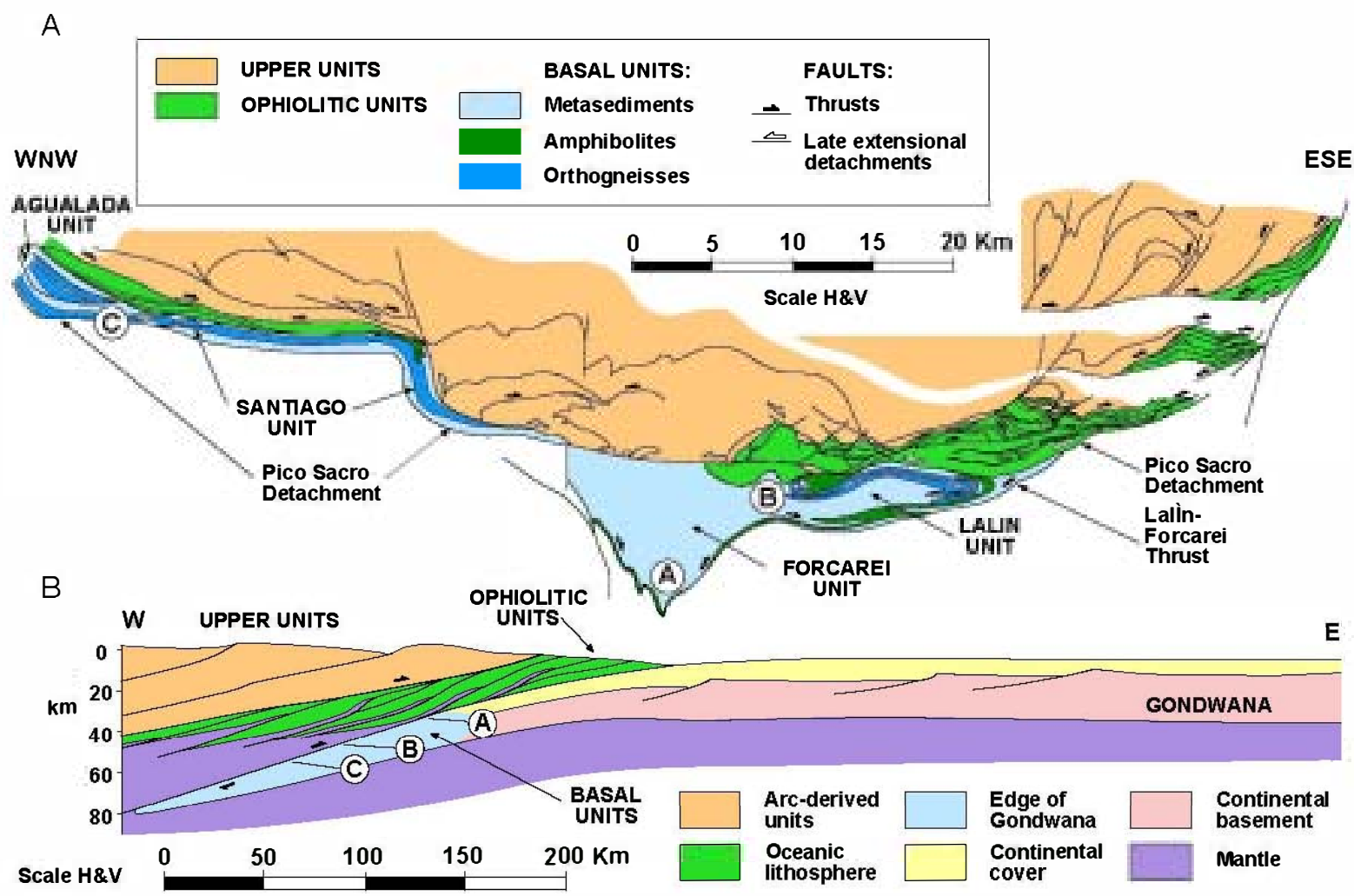

Fig. 2. A: Schematic geological composite section across the Ordenes Complex depicting the relationships among the three groups of allochthonous units and the internal stucture of the Basal Units (after Martinez Catalán et al., 2002). A, B and C show locations where $\boldsymbol{P}-T$ estimations were made by Arenas et al. (1995) and Martinez Catalán et al. (1996). B: Tectonic model showing the subduction of the outernost edge of northern Gondwana, represented by the Basal Units, below an accretionary prism formed by the Upper and Ophiolitic Units in stages prior to the Variscan collision. The approximate position of sample locations in the upper part of the subducting slab (A, B and C) allows estimate of angle of subduction.

preservation of subøphiclitic mantle on top of the latter suggest that the Basal Units eccupied the uppermost part of the subducting slab.

These data permit an estimate of the paleosubduction dip. Taking a mean density of $3000 \mathrm{~kg} \mathrm{~m}^{-3}$ for the wedge above the over-riding slab (Fig. 2B), the difference in pressure inferred from metamorphic assemblages corresponds to a depth increment of 22 $\mathrm{km}$. The outcrops use to estimate $P-T$ data $A$ and $C$ (Fig. 3) are presently separated by $89 \mathrm{~km}$ as measured following folded orthogneiss and amphib-lite bodies (Fig. 2A). However, this distance must be reduced because the Santiage Unit was cut and displace at least $5 \mathrm{~km}$ to the $\mathrm{WNW}$ by the Pice Sacr detachment. Furthermøre, the majør recumbent anticline folding the Basal Units caused stretching in both the normal $(54 \mathrm{~km})$ and reverse $(30 \mathrm{~km})$ limbs of the recumbent fold. Strain was concentrated in the reverse limb, where the orthogneisses and amphib- lites were flattened to layers just a few meters thick by shearing along the Lalín-Forcarei thrust (Fig. 2A). Although the stretching carmot be calculated in the absence of reliable strain markers, we may constrain the original distance between $\mathrm{A}$ and $\mathrm{C}$ by estimating the extension between zer (n॰ extension) and one $(100 \%$ extension, possibly exceeded in the reverse limb but unreasonable for the larger normal limb). Removing $5 \mathrm{~km}$ of movement along the Pic Sacr detachment in the direction of the cross section, and between and $42 \mathrm{~km}$ for the stretching in both limbs of the recumbent fold, we estimate the distance from $A$ and $C$ to have been between 84 and $42 \mathrm{~km}$ before folding and extensional faulting. Combining these distances along dip with the depth 


\begin{tabular}{|c|c|c|c|}
\hline $\begin{array}{l}\text { Location and high-P } \\
\text { metamorphism }\end{array}$ & High-P mineral assemblages & $P-T$ values & Methods used for $\boldsymbol{P}-T$ calculations \\
\hline $\begin{array}{l}\text { Eclogite facies. } \\
\text { Metapelites: gamet zone. } \\
\text { Metabasites: eclogites and } \\
\text { amphibolites in the } \\
\text { homblende-gamet zone. }\end{array}$ & 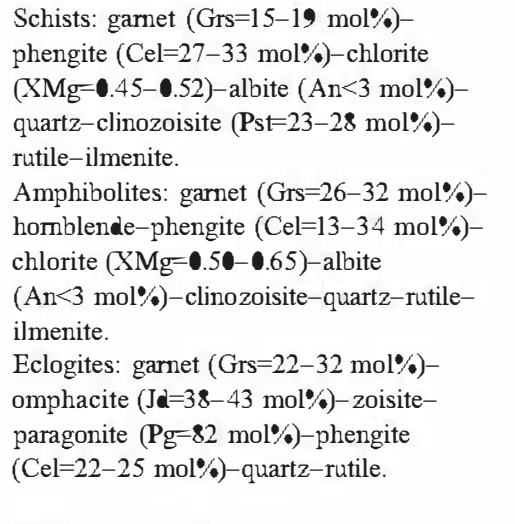 & $520^{\circ} \mathrm{C} 1.65 \mathrm{GPa}$ & $\begin{array}{l}\text { Metapelites: } \\
\text {-Garnet-phengite thermome (Green } \\
\text { and Hellman, 1982; Hynes and Forest, } \\
\text { 1988; Krogh and Rảheim, 1978). } \\
\text {-Garnet-chlorite thermome (Ghent } \\
\text { et al., 1987). } \\
\text {-GRIPS baromery (Bohlen and } \\
\text { Liotta, 1986). } \\
\text {-Phengite barome (Massone and } \\
\text { Schreyer, 1987). }\end{array}$ \\
\hline $\begin{array}{l}\text { Metapelites: gamet zone. } \\
\text { Metabasites: glaucophane- } \\
\text { homblende-gamet zone. }\end{array}$ & & & $\begin{array}{l}\text { Metabasites: } \\
\text {-Garnet-clinopyroxene thermome } \\
\text { (Krogh, 1988). }\end{array}$ \\
\hline $\begin{array}{l}\text { A: Forcarei Unit. } \\
\text { (Lowest part of the unit). }\end{array}$ & $\begin{array}{l}\text { Micaschists: phengite-chlorite- }- \text { garnet- } \\
\text { albite-quartz-rutile-ilmenite. } \\
\text { Greenschists: lawsonite (pseudomorphed by }\end{array}$ & $430^{\circ} \mathrm{C} 1 . \mathrm{GPa}^{\circ}$ & $\begin{array}{l}\text { (Graham and Powell, 1984). } \\
\text {-Jadeite-albite-quartz barome ry } \\
\text { (Holland, 1980, 1983). }\end{array}$ \\
\hline
\end{tabular}

increment, the dip of subduction ranges between 15 and $32^{\circ}$.

Other geolegical data of interest to the models are the age of the oceanic crust subducted before the continental margin of Gondwana and the rate of convergence during the closure of the Rheic Ocean.

Oceanic crust of the youngest ophiølitic unit in the Ordenes Complex has been dated at $395 \mathrm{Ma}$ (U$\mathrm{Pb}$ in zircons; Díaz García et al., 1999; Pin et al., 2002). This and similar units were underthrust between 390 and 380 Ma (Peucat et al., 1990; Dallmeyer et al., 1991, 1997), as deduced from ${ }^{40} \mathrm{Ar}{ }^{39} \mathrm{Ar}$ ages of the amphibølite-facies foliation. The subduction of the continental margin represented by the Basal Units is constraine by ${ }^{40} \mathrm{Ar} /{ }^{39} \mathrm{Ar}$ geochrøn॰løy of phengites in ecløgites, dated arøund 370-365 Ma (Rødríguez et al., 2003). Consequently, $\bullet$ ceanic crust generation of the youngest $\bullet$ phi litic unit preceded continental subduction by 20-25 m.y. In addition, any thermal effect of that young $\bullet$ ceanic lithosphere would have been masked by the subsequent subduction of $\bullet$ lder $\bullet$ phiølites that formed adjacent to the Gondwana margin at the beginning of the Early Ordovician (Arenas et al., 2004; Sánchez Martínez et al., 2004), and the thermal regime of the subduction zone probably equilibrated under conditions controlled by subduction of ๑lder lithosphere with limited heat transfer from the asthenøsphere. 


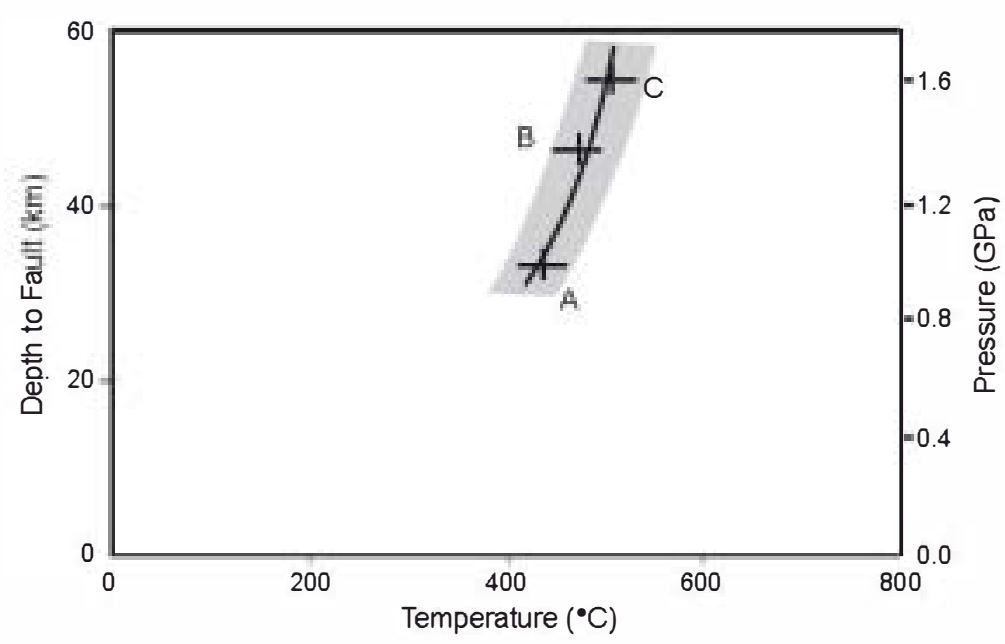

Fig. 3. Pressure-temperature conditions near the top of the Basal Units of the Ordenes Complex, according to Arenas et al. (1995, 1997) and Martínez Catalán et al. (1996). See Fig. 2 for sample location and Table 1 for data used in thermobaromeny. Error bars are approximate.

T- assess the rate of convergence, we use the continental reconstructions based on palemagnetism. According to Scotese and McKerrow (1990) and Scotese (2002), Laurentia and Baltica jøined each -ther by the Middle Silurian (425 Ma) and their søuthern margins were separated from northern Gondwana by an arc of $20-25^{\circ}$, equivalent to 2200 $2800 \mathrm{~km}$. Assuming that the subduction of the Basal Units represents the closure of the Rheic Ocean, and that it started $\approx 385 \mathrm{Ma}$, the convergence rate can be estimated between 5 and $7 \mathrm{~cm}_{\text {year }}{ }^{-1}$.

\section{Estimating shear stress}

Mølnar and England (1990) presented a mathematical sølution for estimating temperatures along the surface of subducted lith $\bullet$ sphere for systems that have reache thermal equilibrium:

$$
T=\left\{\left(Q_{\mathrm{b}}+\tau V\right) z / k\right\} / S
$$

where $S$ is a term that approximates the effect of advection on the system. The value of $S$ is given by

$S=1+\left\{b\left[\left(V_{z} \sin \delta\right) / \kappa\right]^{05}\right\}$

Table 2 lists symbols, units and representative values used in Eqs. (1) and (2).

The term $b$ is a numerical constant that serves as a correction for changes in the amount of heat added to a particular increment of the fault as compared to the average heat added to thrust by shear stress. In the case of constant shear stress, $b$ is equal to 1.0 because the average stress and stress at any point along the thrust are equal. However, if shear heating increases linearly with depth (constant cøefficient of friction) then the heat added at depth $z$ will be greater than the average heat added to the fault surface abøve depth $z$. Mølnar and England (1990)

Table 2

Equations and parameters used to estimate shear stress

Eq. (1)
(Molnar and

England, 1990)

Eq. (2)

(Molnar and

England, 1990)

\begin{tabular}{|c|c|c|}
\hline $\boldsymbol{e}_{\mathrm{b}}$ & $\begin{array}{l}\text { Heat to base of lithosphere } \\
\left(\mathrm{W} \mathrm{m}^{-2} \text { ) }\right.\end{array}$ & $0.05^{\mathrm{a}}$ \\
\hline$\tau$ & Shear stress $(\mathrm{MPa})$ & \\
\hline$V$ & Velocity of subduction $\left(\mathrm{m} \mathrm{s}^{-1}\right)$ & \\
\hline$z$ & $\begin{array}{l}\text { Depth from surface } \\
\text { perpendicular to fault } \\
\text { plane }(\mathrm{m})\end{array}$ & \\
\hline$k$ & $\begin{array}{l}\text { Thermal conductivity } \\
\left(\mathrm{W} \mathrm{m} \mathrm{m}^{-1} \mathrm{~K}^{-1}\right)\end{array}$ & $2.5^{\mathrm{a}}$ \\
\hline s & Dip of fault plane & \\
\hline 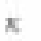 & Thernal diffusivity $\left(\mathrm{m}^{2} \mathrm{~s}^{-1}\right)$ & $8.3 \times 10^{-07 a}$ \\
\hline \multirow[t]{2}{*}{7} & Coefficient of friction & \\
\hline & Density $\left(\mathrm{kg} \mathrm{m}^{-3}\right)$ & $3000^{\mathrm{a}}$ \\
\hline
\end{tabular}

${ }^{a}$ Values used in most numerical and mathematical solutions. 
and Peacock (1992) set $b=1.33$ to correct for this effect and reported that results obtained from this value are consistent with results obtained from finitedifference numerical experiments that model the process.

In this investigation, we first used the mathematical solution to estimate shear heating along the thrust necessary to create the thermal conditions inferred from the metamørphic assemblages of the Basal Units of the Ordenes Complex. However, as is shown below, temperatures experienced by the Basal Units do not conform to either a constant shear force or a constant coefficient of friction. Instead, the geotherm along the thrust surface flattens above a threshold temperature and (or) pressure implying that shear stress decreases above that threshøld. This result is consistent with the expected rhe $\bullet$ gical prøperties of crustal røck.

Because the numerical solution assumes either a cønstant shear stress or cønstant cøefficient of friction, it is not appropriate to use the approach to infer relationships between shear stress and temperature if shear stress is temperature dependent. F $\bullet$ this reasøn, a tw-dimensiønal fïnite-difference model was employed to include feedback between shear stress and temperature aløng the thrust. Shear stress abøve the threshøld of $400^{\circ} \mathrm{C}$ was calculated using the equation

$\tau_{z}=\tau^{*} \operatorname{Exp}\left(-\left(\right.\right.$ temp $\left.\left._{z-1}-400\right) / 75\right)$

where $\tau_{z}$ is the shear stress at depth $z$ and temp $p_{z-1}$ is the temperature of the thrust at depth $z-1$ (after Peacock, 1996). Fig. 4 presents a schematic representation of the numerical model.

\section{Model results and discussion}

Figs. 5, 6 and 7 summarize estimates of the strength of the shear stress acting on the subducting slab necessary to produce metamorphic conditions that affected the Basal Units. Alsø shown are results from experiments used to determine the effect of changing the value of specific variables on temperature estimates resulting from a given shear stress. Using best estimates $\bullet$ initial conditions $\left(\delta=20^{\circ}, V=6\right.$ $\mathrm{cm}$ year $^{-1}$, and $\boldsymbol{Q}_{\mathrm{b}}=\mathbf{0 . 0 5}$ ) shear stress acting at the thrust was $\approx 100 \mathrm{MPa}$ or $10.0 \%$ of pressure between 0 and $30 \mathrm{~km}$. If forces are averaged to depths of 60 $\mathrm{km}$, shear stress was less, $\approx 85 \mathrm{MPa}$ or $3.5 \%$ of pressure. This decrease in average shear stress with depth is best explaine if shear forces decreased when a threshøld temperature and (or) pressure was exceeded. Models that place that threshold at 400 - $\mathrm{C}$ provide a good fit with the observed conditions (Fig. 7).

\section{Robustness of results}

A number of issues might affect the confidence that $\bullet$ ne can place in these estimates of shear stress. First, the mathematical sølution used applies only to systems that have attaine thermal equilibrium. However, if rates of shear heating decreased rapidly above the threshold temperature, then equilibrium would be reached relatively quickly in rocks at depth. A numerical model has been used to test this hypothesis and shows that within 5 m.y. $(V=6 \mathrm{~cm}$ year $\left.{ }^{-1}, \delta=20^{\circ}\right)$, the thrust surface has experienced

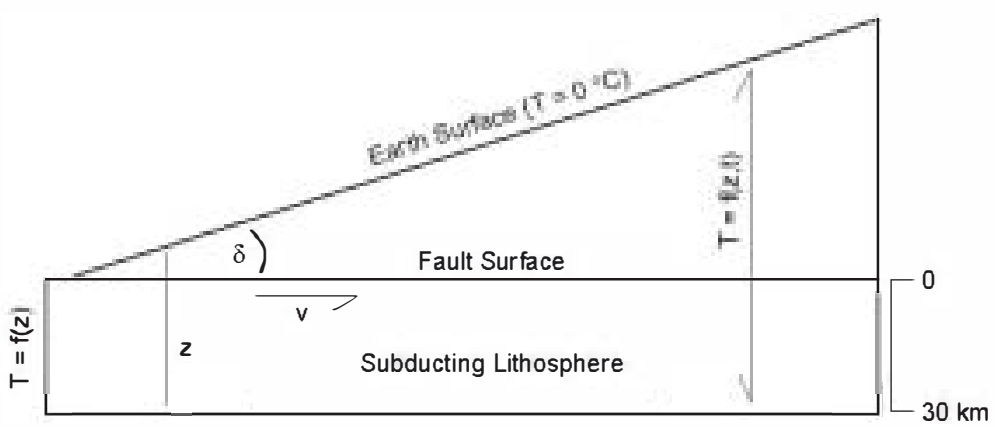

Fig. 4. Visual representation of finite-difference model used to estimate shear stress and the effect of negative feedback between shear stress and temperature above the threshold temperature of $400^{\circ} \mathrm{C}$. 

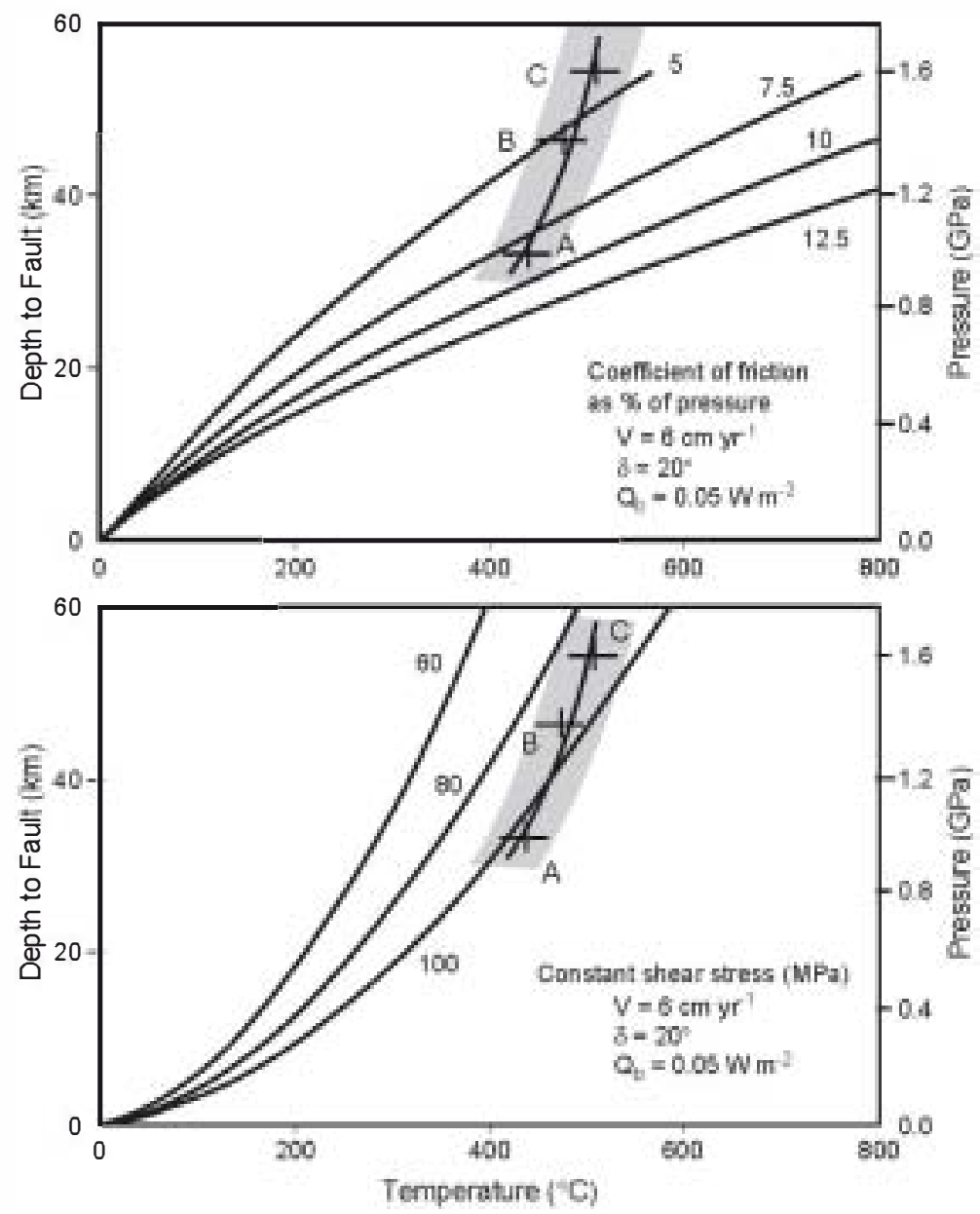

Fig. 5. Estimated temperature along a thrust derived from Eq. (1) (Molnar and England, 1990) assuming constant coefficient of friction or constant shear stress. A comparison of results with other estimates of shear heating by other methods indicates that a constant coefficient of friction better approximates shear stress until depths of sublucted rocks excee $30 \mathrm{~km}$. At greater depths negative feedback reduces shear stress and acts to stabilize temperature. Poin $\mathrm{A}, \mathbf{B}$, and C refer to the sample locations identifed in Fig. 2. Shaded area includes estimate of uncertainty.

$\mathbf{9 3 \%}$ of the coling required to reach equilibrium (Fig. 8). It follows that the deeper portions of the underthrust would have approached equilibrium within the 15 to 20 m.y. that eccurred between subduction of the youngest ophiolitic unit and the subduction of the Gondwanan margin rocks that form the Basal Units.

A large change in the angle of subduction will result in significant differences in the temperature of the underthrust for a given amount of shear stress. The lower the angle, the higher the temperature at depth $z$ because the rock must travel farther and experience more shearing to reach that depth. The effect of the angle $\bullet$ subduction $\bullet$ shear heating for a given shear stress is presented in Fig. 6B As discussed below, estimates of shear stress reported here are higher than estimates reported elsewhere, it seems unlikely, therefore, that the dip of subduction was significantly greater than $20^{\circ}$.

A third consideration is the age of the $\bullet$ ceanic crust that was subducted prior to invelvement of the continental margin. Young $\bullet$ ceanic crust with higher heat flow to the surface and higher getherm has been shown to affect the seismic properties of subducting crust (Peaceck and Wang, 1999). Hewever, as seen in 

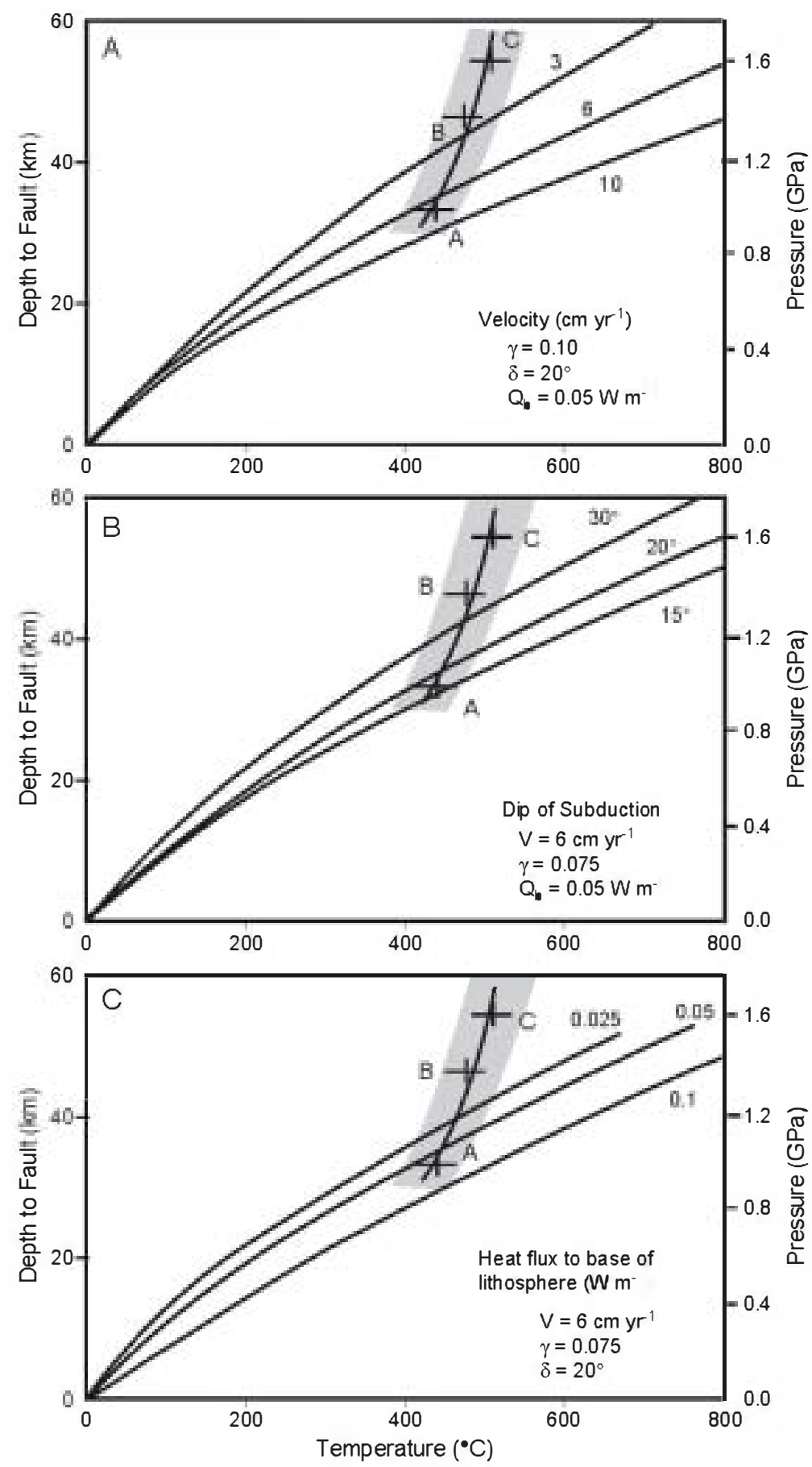

Fig. 6. Comparison of model temperatures along underthrust with temperature gradient inferred from metamorphic assemblages found near the upper surface of the Basal Units. Points A, B, and C refer to the sample locations identifed in Fig. 2. Shaded area includes estimate of uncertainty: Figures show : A: Effect of velocity on heating resulting from shear stress, $\mathbf{B}$ : Effect of the dip of subduction on heating of the thrust surface, and C: Effect of heat flux to the base of the lithosphere $\left(\boldsymbol{Q}_{\mathbf{b}}\right)$ on thermal character of the thrust surface. Model parameters are included in each frgure. 


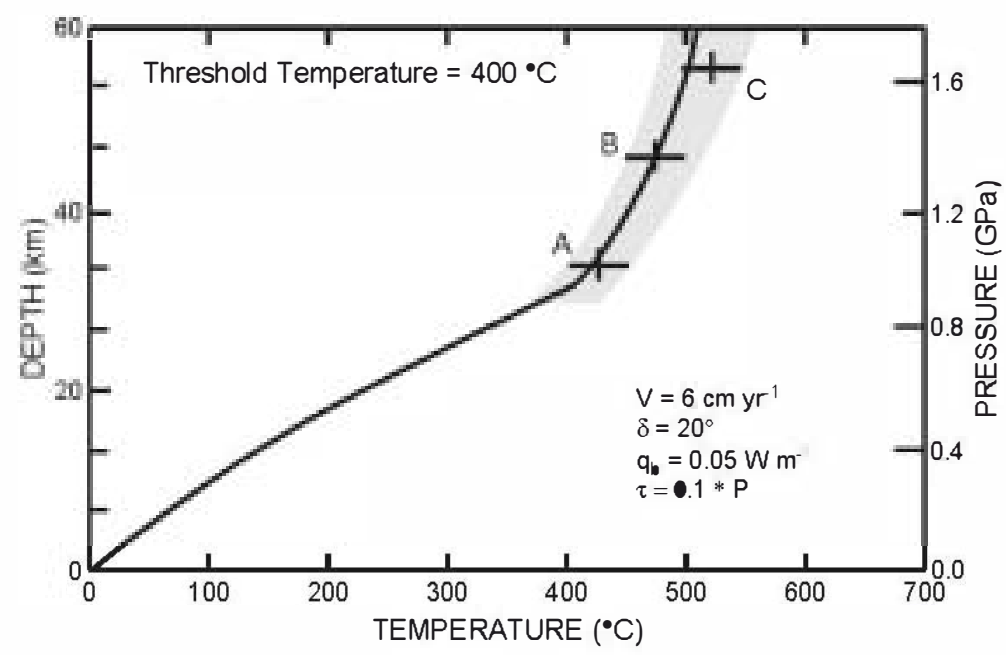

Fig. 7. Best-fit model based on a constant coefficient of friction at temperatures less than the brittle-plastic ransition set at $40{ }^{\circ} \mathrm{C}$ and exponentially decreasing shear stress if temperature exceeds the ransition. Results obtained from two-dimensional finite-difference model.

Fig. 6C, the effect of increasing basal heat flow on predicted temperatures at depth is relatively small. A doubling of heat flow from $0.05 \mathrm{~W} \mathrm{~m}^{-2}$ t॰ $0.10 \mathrm{~W}$ $\mathrm{m}^{-2}$ is equivalent to an increase of the coefficient of friction from $8 \%$ to $10 \%$. The impact would be even smaller at the depths of interest $(30-60 \mathrm{~km})$ because negative feedback between temperature and shear stress acts to limit temperature ab॰ve $\approx 400^{\circ} \mathrm{C}$.

Perhaps the most important variable affecting the estimate of shear stress experienced by the Basal Units is the velocity of convergence. The velocity of convergence has been estimated to be between 5 and 7 $\mathrm{cm}$ year $^{-1}$ based on the plate reconstructions of Scotese and McKerrow (1990) and Scotese (2002) and a velocity of $6 \mathrm{~cm}$ year ${ }^{-1}$ has been used in most models. Slower convergence would reduce heating derived from a given amount of shear. The coefficient of friction would have to increase by $>30 \%$ to reach a temperature $\approx 400^{\circ} \mathrm{C}$ at a depth of $33 \mathrm{~km}$ if the convergent rate were 3 , n॰t $6 \mathrm{~cm}$ year $^{-1}$. Rapid convergence of $10 \mathrm{~cm}$ year $^{-1}$ would reduce the necessary coefficient of friction by $\approx 20 \%$ (Table 3 ).

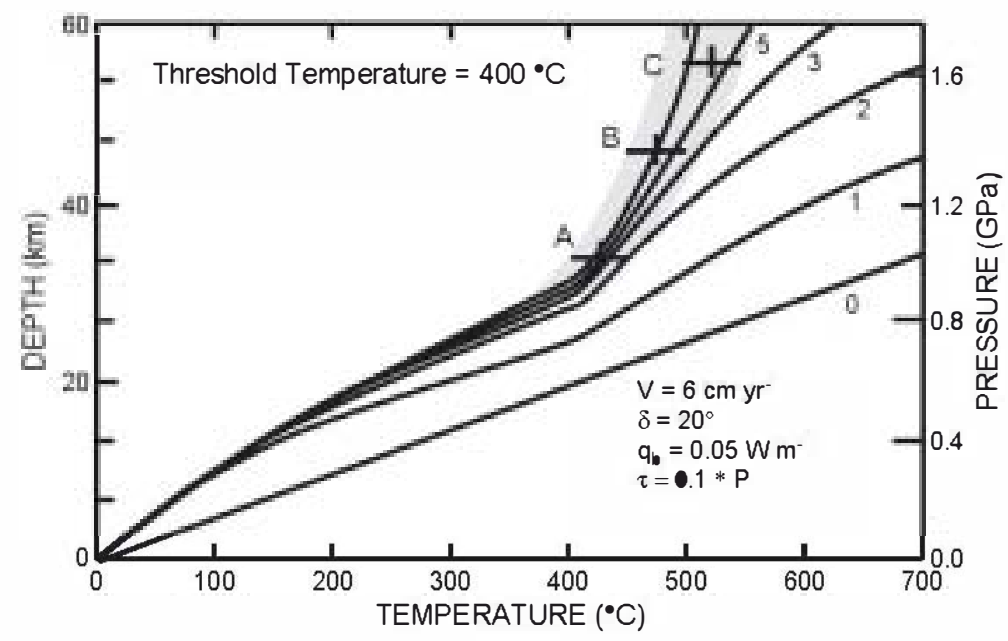

Fig. 8. Development of thermal regime along overthrust as subduction zone approaches thermal equilibrium. Thermal gradient along thrust is shown at $\bullet, 1,2,3$, and 5 m.y. after initiation of subduction. Equilibrium is es ablished after 10 to 15 m.y. 
Representative results from numerical solution

\begin{tabular}{|c|c|c|c|c|}
\hline $\begin{array}{l}\text { Coefficient of } \\
\text { friction }\end{array}$ & Dip & $\begin{array}{l}\text { Velocity } \\
\text { (cm year }{ }^{-1} \text { ) }\end{array}$ & $\begin{array}{l}\text { Temperature } \\
\left({ }^{\circ} \mathrm{C} \text { at } 33 \mathrm{~lm}\right)\end{array}$ & $\begin{array}{l}\text { Temperature } \\
\left({ }^{\bullet} \mathrm{C} \text { at } 55 \mathrm{~km}\right)\end{array}$ \\
\hline \multicolumn{3}{|c|}{$\begin{array}{l}\text { Temperature inferre from mineral } \\
\text { assemblages and compositions }\end{array}$} & 430 & 520 \\
\hline \multirow[t]{6}{*}{0.05} & 15 & 6 & 278 & 532 \\
\hline & & 10 & 319 & 637 \\
\hline & 20 & 6 & 246 & 470 \\
\hline & & 10 & 282 & 561 \\
\hline & 30 & 6 & 208 & 396 \\
\hline & & 10 & 238 & 470 \\
\hline \multirow[t]{6}{*}{0.075} & 15 & 6 & 368 & 733 \\
\hline & & 10 & 440 & 903 \\
\hline & 20 & 6 & 327 & 647 \\
\hline & & 10 & 389 & 795 \\
\hline & 30 & 6 & 276 & 545 \\
\hline & & 10 & 327 & 667 \\
\hline \multirow[t]{6}{*}{ ๑.1 } & 15 & 6 & 458 & 934 \\
\hline & & 10 & 560 & 1169 \\
\hline & 20 & 6 & 407 & 825 \\
\hline & & 10 & 494 & 1030 \\
\hline & 30 & 6 & 344 & 694 \\
\hline & & 10 & 416 & 864 \\
\hline \multirow[t]{6}{*}{ •.125 } & 15 & 6 & 548 & 1134 \\
\hline & & 10 & 680 & 1435 \\
\hline & 20 & 6 & 487 & 1002 \\
\hline & & 10 & 601 & 1264 \\
\hline & 30 & 6 & 412 & 844 \\
\hline & & 10 & 506 & 1061 \\
\hline
\end{tabular}

Bold indicates results consistent with metamorphic conditions.

Finally, the models that provide the best fit to the -bserved data (Fig. 7) have shear stress decrease exponentially at temperatures above a threshøld $\approx 400^{\circ} \mathrm{C}$. This will have the effect of limiting the impact of the uncertainty associated with various parameters to the region of the thrust fault experiencing temperatures below the threshold. Because shear stress decreases rapidly above the thresh $\bullet$ d, the effect of changing the angle of subduction, the velocity of convergence or the heat delivered to the base of the lithosphere become less important to determining the temperature during high-pressure metamorphism. In fact, the results suggest that high-temperature, high-pressure metamørphism requires special circumstances to eccur within subducting crust. Possible causes might be intrusion of high-temperature magmas, the subduction of a spreading ridge, or the preservation of metamorphism that occurred during the initial stages of subduction before thermal equilibration.

\section{Comparisons with results from other methods}

Estimates of shear heating in subduction zones made using heat flow measurements above ten circum-Pacific subduction zones are $14 \mathrm{MPa}$ (cønstant shear stress) or $5.9 \%$ of pressure (constant cœefficient $\bullet$ friction) (Tichelaar and Ruff, 1993). A study of heat flow in the Central Andes yielded similar results (Springer, 1999); however, a recent study of heat flow in the Kermadec forearc yields significantly higher estimates of shear stress (Von Herzen et al., 2001). The latter study did not consider the contribution of radiogenic heating in the hanging wall to surface heat flow and so may -verestimate shear forces. The significant difference between estimates of constant shear stress and better agreement between estimates of the coefficient of friction reported by Tichelaar and Ruff (1993) and in this study suggest that these differences may be caused by differences in methodoløgy. Møst likely the low estimates of constant shear stress derive from Tichelaar and Ruff's interest in the upper reaches of the subduction zone where the fault is seismically active. At a depth of 10-15 km, temperatures of the fault surface inferred from Tichelaar and Ruff's estimates of shear stress as constant shear stress or as a cønstant cøefficient of friction are similar. With increasing depth, the difference in temperature derive from the two models increases, with temperatures predicted by a constant cøefficient of friction becoming significantly higher than those based on constant shear stress.

Tichelaar and Ruff (1993), Ruff and Tichelaar (1996) als used their estimate of shear stress to calculate temperature at the transition of the fault from seismically active to quiescent behavior. Using a constant coefficient of friction, they estimate that the transition $\bullet$ ccurs at $\approx 400^{\circ} \mathrm{C}$ if subduction $\bullet$ ccurs beneath thickened crust. This value is again consistent with best-fit models of shear stress acting on the Basal Units.

The better agreement between estimates of the coefficient $\bullet$ friction $\bullet$ btained by Tichelaar and Ruff (1993) and by this study and the significant difference between results $\bullet$ btained from constant shear stress indicate that shear stress is best modeled as a pressuredependent variable. Althøugh estimates of the cøefficient of friction derived from the different studies are 
similar, the estimates reported here that are based on metamorphism of the Basal Units are significantly higher, $10 \%$ to $5.9 \%$. The source of this difference is uncertain. It may be caused by differences in the subduction zones themselves. For example, the rhe løgical properties of continental margin rocks $\bullet$ the Basal Units may be sufficiently different from basaltic eceanic crust to change shear heating in the subduction zone.

The presence of blueschists and eclogites among exhume recks has als been used to constrain thermal conditions within subduction zones (Peacock, 1992, 1996). However, because most exposures of these rocks are of limited extent and bounded by later faults associated with their uplift and retum to the surface, their position within the subducted crust is not well constrained. If they originally were in the interior of the subducted lithosphere, away from the fault surface, then shear heating would have less impact on them. Should these rocks be used to estimate temperatures along the thrust and by extension the amount of shear heating required to produce those temperatures, they would yield underestimates -f both. Furthermore, evidence derived from the Basal Units implies that shear stress decreases above a threshold temperature. It follows that single exposures - moderate-temperature, high-pressure metamorphic rocks can only be used to estimate the average shear stress that affected the rocks during underthrusting. Estimating actual shear stress at any particular depth requires a more complete image of the subduction zone, similar to that obtained from the multiple expøsures $\bullet$ the Basal Units of the Ordenes C॰mplex.

\section{Conclusion}

Exposures in the Ordenes Complex of continental margin rocks that were subducted to depths ranging between 30 and $60 \mathrm{~km}$ provide a view of these portions of a pale-subduction zone. Temperatures and depths derived from study of the high-pressure, moderate-temperature metamorphism of these rocks and the dip of subduction estimated from structural reconstructions constrain estimates of shear forces acting along the underthrust. Best estimates are that shear stress was $\approx 10 \%$ of pressure at temperatures below a threshold of $400^{\circ} \mathrm{C}$. Once temperature exceeded the threshøld, the coefficient of friction decayed expenentially.

Additionally, the decrease in shear stress above the threshold implies a negative feedback between shear stress and temperature. Negative feedback tends to stabilize system behavior and sø causes temperature and shear stress to appreach constant values. One implication is that moderate-temperature metamorphism of high-pressure and ultra-high-pressure røcks can $\bullet$ nly be used to estimate average shear stress in the subduction zone abøve thøse røcks. The results als imply that high-temperature, high-pressure metamorphism should be rare in subducting crust because it requires an additional heat source, distinct from the normal processes of subduction.

\section{Acknowledgements}

Field and petrological work in NW Spain was funded by the Spanish agencies Dirección General de Investigación Científica y Técnica and Dirección General de Enseñanza Superiør e Investigación Científica, and includes results frøm prøjects PB880145-C 2, PB91-0192-C2, PB94-1396-C2 and PB 97-0234-C 2. Additional support has been previded by a Faculty Develøpment Grant of the Abington College, Penn State University. We thank V. Tenczer and Jean Pierre Burg for thøughtful reviews of an earlier version of this paper.

\section{References}

Andonaegui, P., González del Tánago, J., Arenas, R., Abati, J., Martínez Catalán, J.R., Peinado, M., Díaz García, F., 2002. Tectonic setting of the Monte Castelo gabbro (Ordenes Complex, northwestern Iberian Massif): evidence for an arcrelated terrane in the hanging wall to the Variscan suture. In: Martínez Catalán, J.R., Hatcher, R.D., Arenas, R., Díaz García, F. (Eds.), Variscan-Appalachian Dynamics: The Building of the Late Paleozoic Basement, Spec. Pap. - Geol. Soc. Am., vol. 364, pp. $37-56$

Arenas, R., Rubio Pascual, F.J., Díaz García, F., Martínez Catalán, J.R., 1995. High-pressure micro-inclusions and development of an inverted metamorphic gradient in the Santiago Schists (-rdenes Complex, NW Iberian Massif; Spain): evidence of subduction and syn-collisional decompression. J. Metamorph. Geol. 13, 141-164. 
Arenas, R., Abati, J., Martínez Catalán, J.R., Díaz García, F., Rubio Pascual, F.J., 1997. $\boldsymbol{P}-T$ evolution of eclogites from the Agualada Unit (Ordenes Complex, NW Iberian Massif, Spain): implications for crustal subduction. Lithos 4., 221-242.

Arenas, R., Martínez Catalán, J.R., Sánchez Martínez, S., Díaz García, F., Abati, J., Femández-Suárez, J., 2004. Paleozoic ophiolites in the Variscan suture of Galicia (NW Spain): distribution, characteristics and meaning. 2004 Intemational basement tectonics Association Conference: 4-D framework of continental crust, Oak Ridge, Tennessee, pp. 82-84. Program with Abs racts.

Bohlen, S.R., Liotta, J.L., 1986. A barometer for gamet amphibolites and gamet granulites. J. Petrol. 27, 1025-1034.

Dallmeyer, R.D., Ribeiro, A., Marques, F., 1991. Polyphase Variscan emplacement of exotic terranes (Morais and Bragança Massifs) onto Iberian successions: evidence from ${ }^{40} \mathrm{Ar} /{ }^{39} \mathrm{Ar}$ mineral ages. Lithos 27, 133-144.

Dallmeyer, R.D., Martínez Catalán, J.R., Arenas, R., Gil lbarguchi, J.I., Gutiérrez Alonso, G., Farias, P., Aller, J., Bastida, F., 1997. Diachronous Variscan tectonothermal activity in the NW Iberian Massif: evidence from ${ }^{40} \mathrm{Ar} /{ }^{39} \mathrm{Ar}$ dating of regional fabrics. Tectonophysics 277, 307-337.

Díaz García, F., Arenas, R., Martínez Catalán, J.R., González del Tánago, J., Dunning, G., 1999. Tectonic evolution of the Careón ophiolite (Northwest Spain): a remnant of oceanic lithosphere in the Variscan belt. J. Geol. 107, 587-605.

England, P.C., Richardson, S.W., 1977. The influence of erosion upon the mineral facies of rocks from different metamorphic environments. J. Geol. Soc. (Lond.) 134, 210-213.

England, P.C., Thompson, A., 1984. Pressure-temperature-time paths of regional metamorphism: I. Heat transfer during evolution of regions of thickened crust. J. Petrol. 25, 894-928.

Emst, W.G., Peacock, S.M., 1996. A thermotectonic model for preservation of ul trahigh-pressure phases in metamorphosed continental crust. In: Bebout, G.E., Scholl, D.W., Kirby, S.H., Platt, P. (Eds.), Subduction Top to Bottom, Am. Geophys. Union, Geophys. Monogr., vol. 96, pp. 171-178.

Ghent, E.D., Stout, M.Z., Black, P.M., Brothers, R.N., 1987. Chloritoid-bearing rocks associated with blueschists and eclogites, northem New Caledonia. J. Metamorph. Geol. 5, $239-254$.

Graham, C.M., England, P.C., 1976. Thermal regimes and regional metamorphism in the vicinity of overthrust faults: an example of shear heating and inverted metamorphic zonation from southern Califomia. Earth Planet. Sci. Lett. 31, 142-152.

Graham, C.M., Powell, R., 1984. A gamet-homblende geothermometer: calibration, testing and applications to the Pelona Schist, Southem Califomia. J. Metamorph. Geol. 2, 13-31

Green, T.H., Hellman, P.L., 1982. Fe-Mg partitioning between coexisting garnet and phengite at high pressure, and comments on a gamet-phengite geothermometer. Lithos 15, 253-266.

Holland, TJ.B., 1980. The reaction albite=jadeite+quartz determined experimentally in the range $600-1200^{\circ} \mathrm{C}$. Am. Mineral. $65,129-134$.

Holland, T.J.B., 1983. The experimental determination of activities in disordere and short-range ordered jadeitic pyroxenes. Contrib. Mineral. Petrol. 82, 214-220.
Hynes, A., Forest, R.C., 1988. Empirical gamet-muscovite geothermome in low-grade metapelites, Selwyn Range (Canadian Rockies). J. Metamoprh. Geol. 6, 297-309.

Kolın, M.J., Spear, F.S., 1990. Two new geobarometers for gamet amphibolites, with applications to southeastem Vermont. Am. Mineral. 75, 89-96.

Krogh, E.J., 1988. The garnet-clinopyroxene Fe-Mg geothermometer-a reinterpretation of existing data. Contrib. Mineral. Petrol. 99, 44-48.

Krogh, E.J., Rảheim, A., 1978. Temperature and pressure dependence of $\mathrm{Fe}-\mathrm{Mg}$ partitioning between gamet and phengite, with particular reference to eclogites. Contrib. Mineral. Petrol. 66, $75-80$.

Martínez Catalán, J.R., Arenas, R., Díaz García, F., Rubio Pascual, FJ., Abati, J., Marquínez, J., 1996. Variscan exhumation of a subducted Paleozoic continental margin: the basal units of the Ordenes Complex, Galicia, NW Spain. Tectonics 15, 106-121.

Martínez Catalán, J.R., Arenas, R., Díaz García, F., Abati, J., 1997. Variscan accretionary complex of northwest Iberia: Terrane correlation and succession of tectonothermal events. Geology $25,1103-1106$

Martínez Catalán, J.R., Díaz García, F., Arenas, R., Abati, J., Castiñeiras, P., González Cuadra, P., Gómez Barreiro, J., Rubio Pascual, F., 2002. Thrust and detachment systems in the Ordenes Complex (northwestern Spain): implications for the Variscan-Appalachian geodynamics. In: Martínez Catalán, J.R., Hatcher, R.D., Arenas, R., Díaz García, F. (Eds.), VariscanAppalachian Dynamics: The Building of the Late Paleozoic Basement, Spec. Pap. - Geol. Soc. Am., vol. 364, pp. 163-182.

Massone, H.J., Schreyer, W., 1987. Phengite geobarometry based on the limiting assemblage with $\mathrm{K}$-feldspar, phlogopite, and quartz. Contrib. Mineral. Petrol. 96, 212-224.

Molnar, P., England, P., 1990. Temperatures, heat flux and frictional stress near major thrust faults. J. Geophys. Res. 95 B 4, $4833-4856$.

Peacock, S.M., 1990. Numerical simulation of metamorphic pressure-temperature-time paths and fluid production in subducting slabs. Tectonics 9, 1197-1211.

Peacock, S.M., 1992. Blueschist-facies metamorphism, shear heating, and $\boldsymbol{P}-T-t$ paths in subduction shear zones. J. Geophys. Res. 97 B12, 17693-17707.

Peacock, S.M., 1996. Thermal and petrologic structure of subduction zones. In: Bebout, G.E., Scholl, D.W., Kirby, S.H., Platt, P. (Eds.), Subduction Top to Bottom, Am. Geophys. Union, Geophys. Monogr., vol. 96, pp. 119-133.

Peacock, S.M., Wang, K., 1999. Seismic consequences of warm versus cool subduction zone metamorphism: examples from southwest and northeast Japan. Science 286, 937-939.

Peucat, J.J., Bemard-Griffiths, J., Gil Ibarguchi, J.I., Dallmeyer, R.D., Menot, R.P., Comichet, J., Iglesias Ponce de León, M., 1990. Geochemical and geochronological cross section of the deep Variscan crust: the Cabo Ortegal high-pressure nappe (northwestem Spain). Tectonophysics 177, 263-292.

Pin, C., Paquette, J.L., Santos Zalduegui, J.F., Gil Ibarguchi, J.I., 2002. Early Devonian supra-subduction zone ophiolite related to incipient collisional processes in the Western Variscan Belt: the Sierra de Careón unit, Ordenes Complex, Galicia. 
In: Martínez Catalán, J.R., Hatcher, R.D., Arenas, R., Díaz García, F. (Eds.), Variscan-Appalachian Dynamics: The Building of the Late Paleozoic Basement, Spec. Pap. - Geol. Soc. Am. 364, pp. 57-72.

Rodríguez, J., Cosca, M.A., Gil Ibarguchi, J.I., Dallmeyer, R.D., 2003. Strain partitioning and preservation of $40 \mathrm{Ar} / 39 \mathrm{Ar}$ ages during Variscan exhumation of a sublucted crust (Malpica-Tui complex, NW Spain). Lithos 70, 111-139.

Rubio Pascual, F.J., Arenas, R., Díaz García, F., Martínez Catalán, J.R., Abati, J., 2002. Eclogites and eclogite-amphibolites from the Santiago Unit (Ordenes Complex, NW Iberian Massif; Spain): a case study of contrasting high-pressure metabasites in a context of crustal subduction. In: Martínez Catalán, J.R., Hatcher, R.D., Arenas, R., Díaz García, F. (Eds.), VariscanAppalachian Dynamics: The Building of the Late Paleozoic Basement, Spec. Pap. - Geol. Soc. Am., vol. 364, pp. 105-124.

Ruff, L.J., Tichelaar, B.W., 1996. What controls the seismogenic plate interface in subduction zones? In: Bebout, G.E., Scholl, D.W., Kirby, S.H., Platt, J.P. (Eds.), Subduction Top to Bottom, Am. Geophys. Union, Geophys. Monogr., vol. 96, pp. 105-111.

Sánchez Martínez, S., Arenas, R., Andonaegui, P., Martínez Catalán, J.R., 2004. Geochemis of two associated ophiolites from the Cabo Ortegal Complex (Variscan Belt of NW Spain). 2004 Intemational basement Tectonics Association Conference: 4-D framework of continental crust, Oak Ridge, Tennessee, pp. 71-73. Program with Abstracts.

Scotese, C.R., 2002. Paleomap project. http://rww.scotese.com/. Scotese, C.R., McKerrow, W.S., 1990. Revised World maps and introduction. In: McKerrow, W.S., Scotese, C.R. (Eds.), Paleozoic Paleogeography and Biogeography, Mem. - Geol. Soc., vol. 12, pp. 1-22.

Springer, M., 1999. Interpretation of heat-flow density in the Central Andes. Tectonophysics 306, 377-395.

Tichelaar, B.W., Ruff, L.J., 1993. Depth of seismic coupling along subduction zones. J. Geophys. Res. 98 B2, 2017-2037.

van der Beukel, J., Wortel, R., 1987. Temperature and shear stresses in the upper part of a subduction zone. Geophys. Res. Lett. 14, $1057-1060$.

Von Herzen, R., Ruppel, C., Molnar, P., Nettles, M., Nagihara, S., Ekstrom, G., 2001. A constraint on the shear stress at the Pacific-Australian plate boundary from heat flow and seismiscity at the Kermadec forearc. J. Geophys. Res. 106 B4, 6817-6833. 